\title{
Expression of recombinant membrane-bound type I iodothyronine deiodinase in yeast
}

\author{
George G J M Kuiper, Willem Klootwijk and Theo J Visser \\ Department of Internal Medicine, Room Ee 502, Erasmus Medical Center, PO Box 1738, 3000 DR Rotterdam, The Netherlands \\ (Requests for offprints should be addressed to T J Visser; Email: t.j.visser@erasmusmc.nl)
}

\begin{abstract}
The bioactivity of thyroid hormone is determined to a large extent by the monodeiodination of the prohormone thyroxine (T4) by the hepatic selenoenzyme type I iodothyronine deiodinase (D1), i.e. by outer ring deiodination (ORD) to the active hormone triiodothyronine (T3) or by inner ring deiodination (IRD) to the inactive metabolite reverse T3 (rT3). Since D1 is a membrane-bound protein with an N-terminal membrane-spanning domain, the enzyme is very difficult to purify in an active state. This study was undertaken in order to develop a heterologous (over)-expression system that would eventually allow the production of large amounts of purified active D1 protein. We have expressed a mutant rat D1 protein, in which the selenocysteine residue in the core catalytic center was replaced by cysteine (D1 Cys) in yeast cells (Saccharomyces cerevisiae). After yeast cell fractionation, kinetic analysis was performed with dithiothreitol as reducing cofactor. ORD activity was associated with membrane fractions, while no activity could be detected in the cytosolic fraction. The D1 Cys protein displayed a tenfold increase in $K_{\mathrm{m}}(2 \mu \mathrm{M})$ for rT3 as compared with native D1 protein in rat liver microsomes. The D1 protein content is about $65 \mathrm{pmol} / \mathrm{mg}$ microsomal protein, as compared with about $3 \mathrm{pmol} / \mathrm{mg}$ in rat liver microsomal fraction. SDS-PAGE analysis of $N$-bromoacetyl-[125/]T3 affinity-labeled D1 protein showed several labeled protein isoforms with apparent molecular masses between 27 and $32 \mathrm{kDa}$. Immunoblot analysis with a specific D1 antiserum confirmed the observed D1 protein heterogeneity. Site-directed mutagenesis of several potential $\mathrm{N}$-linked glycosylation sites, phosphorylation sites and a unique myristoylation site established that D1 heterogeneity is not caused by N-linked glycosylation, but probably by a combination of O-linked glycosylation and phosphorylation. Deletion of the endoplasmic reticulum (ER)-signal sequence and the membrane-spanning domain (amino acid residue 2-35), did not result in the production of a soluble D1 enzyme. Although this mutated D1 protein is inactive, the fact that it is still membrane bound indicates the existence of additional membrane attachment site(s) or membrane-spanning domains. Overall, our studies indicate that yeast cells provide a useful system for the expression of relatively high levels of D1 protein which could be used for further structure-function analysis.
\end{abstract}

Journal of Molecular Endocrinology (2005) 34, 865-878

\section{Introduction}

The type I iodothyronine deiodinase (D1) selenoprotein is found in mammals predominantly in the microsomal fractions of liver, kidney and thyroid gland (Bianco et al. 2002, Köhrle 2002, Kuiper et al. 2005). This enzyme is responsible for a large part of the peripheral production of 3,3',5-triiodothyronine (T3) from thyroxine (T4) in euthyroid animals (Doorn et al. 1983, Nguyen et al. 1998, Bianco et al. 2002). Remarkably, D1 is capable of both outer ring deiodination (ORD) and inner ring deiodination (IRD) of T4, and shows preference for reverse T3 (rT3; 3,3',5'-triiodothyronine) as the substrate (Berry et al. 1991a, Moreno et al. 1994). D1 activity in vitro is stimulated by thiol compounds such as dithiothreitol (DTT) and is uncompetitively inhibited by 6-propyl-2-thiouracil (Visser 1980).
$\mathcal{N}$-bromoacetyl-[125 $]$ T3 has proven to be a useful affinity label of D1, allowing the specific labeling of the enzyme in rat liver microsomal fractions (Schoenmakers et al. 1992), despite the fact that it only constitutes about $0.01 \%$ of protein content (Mol et al. 1988). Progress in the structure-function analysis of Dl protein is hampered by the very low expression level. Due to the low expression level only small amounts of purified D1 protein (approximately 50\% pure) were obtained by affinity chromatography from detergent-solublized microsomal fractions of rat liver (Mol et al. 1988). Molecular sieve chromatography of the detergent solubilized D1 from rat liver or kidney cells yielded a $50 \mathrm{kDa}$ active enzyme preparation, suggesting that the D1 protein is composed of a homodimer of $27 \mathrm{kDa}$ subunits (Mol et al. 1988, Köhrle et al. 1990, Leonard et al. 2001). After the D1 cDNA cloning (Berry et al. 
1991a), site-directed mutagenesis and deletion analysis have identified several functional regions of the D1 protein (Berry et al. 1991b, 1992, Toyoda et al. 1995a,b, 1997, Leonard et al. 2001, Kuiper et al. 2003). The rat D1 protein contains an uncleaved endoplasmic reticulum (ER) transfer sequence and transmembrane domain (amino acid residue 2-35), while iodothyronine substrate selectivity is influenced by the domain between amino acid residues 40 and 70 . The D1 core active center consists of a region of about 20 amino acid residues long, surrounding the single essential selenocysteine (SeC) residue.

At the same time it should be realized that analyzing the effects of individual mutations in impure D1 enzymes only reveals that the changed amino acid residue directly or indirectly affects activity, but does not necessarily deliver reliable information on the molecular mechanism(s) involved. In order to obtain pure D1 protein for more detailed structure-function analysis it is necessary to develop a heterologous (over)-expression system. The fact that D1 is an integral membrane protein limits the choice of expression systems to eukaryotic cells, for instance yeast or insect cells, since expression in bacteria of D1 protein results in the production of inactive D1 that accumulates in inclusion bodies (G GJ M Kuiper, W Klootwijk \& TJ Visser, unpublished observations). A heterologous expression system that combines several advantages of both prokaryotic and eukaryotic expression systems are yeasts such as Saccharomyces cerevisiae and Pichia pastoris (Guengerich et al. 1991, Bill 2001, Griffith et al. 2003). Yeast cells can perform proper post-translational modifications, and contain identical secretory pathways as higher eukaryotic cells. Yeast cells can be grown inexpensively in large quantities and several wellcharacterized inducible promoter systems that allow regulated expression of specific genes have been established. Several cytochrome P450 enzymes and short-chain dehydrogenase/reductase enzymes, inserted in membranes in much the same manner as deiodinases, have been succesfully overexpressed in yeast (Guengerich et al. 1991, Blum et al. 2001, Hult et al. 2001).

The $\mathrm{Dl}$ protein contains a single $\mathrm{SeC}$ residue in the catalytic center, encoded by a UGA stop codon. Successful insertion of $\mathrm{SeC}$ at UGA codons in eukaryotes requires the presence of a specific stem-loop structure in the 3'-untranslated region of the mRNA (Berry et al. 1993). Although yeast cells are eukaryotic cells they are unable to synthesize selenoproteins. In fact, the yeast homologs of several higher eukaryotic proteins (glutathione peroxidase, SelX) contains cysteine residues instead of SeC residues (Lescure et al. 1999). In order to overcome this potential problem, we have made D1 expression vectors in which the UGA stop codon encoding SeC incorporation was replaced by UGG (Cys) or UCA (Ser). In the present paper we describe the heterologous expression and characterization of type I deiodinase activity in Saccharomyces cerevisiae.

\section{Materials and methods}

Nonradioactive iodothyronines were obtained from Henning Berlin R\&D (Berlin, Germany) and [3',5'${ }^{125} \mathrm{n}$ rT3 was prepared by radioiodination of $3,3^{\prime}-$ diiodothyronine (T2) as described (Visser et al. 1978). $\left[3^{\prime}-{ }^{125}\right]$ T3 $(1500-2000 \mathrm{mCi} / \mu \mathrm{mol})$ was obtained from Amersham Biotech (Little Chalfont, Bucks, UK). Unlabeled $\mathcal{N}$-bromoacetyl-T3 (BrAcT3) and $\operatorname{BrAc}\left[{ }^{125} \Pi \mathrm{T} 3\right.$ were synthesized from $\mathcal{N}$-bromoacetylchloride and $\mathrm{T} 3$ or $\left[3^{\prime}-{ }^{125} \Pi \mathrm{T} 3\right.$ as described (Mol et al. 1984). HPLC analysis demonstrated that the purity of $\mathrm{BrAc}\left[{ }^{125} \Pi \mathrm{T} 3\right.$ was at least $85 \%$, the remainder being unreacted $\mathrm{T} 3$. Iodoacetate (IAc) and 6-propyl-2-thiouracil (PTU) were obtained from Sigma (St Louis, MO, USA). Rat liver microsomes were prepared as previously described (Fekkes et al. 1979).

The yeast expression vector pYES6/CT and the diploid Saccharomyces cerevisiae strain INVScl (genotype his3 $\triangle 1$; leu2; trp1-289; ura3-52) were obtained from Invitrogen (Carlsbad, CA, USA). The antibiotic blasticidin $\mathrm{S}$ was also obtained from Invitrogen. Peptone, bacto-yeast extract and the yeast nitrogen base without amino acids were from DIFCO Laboratories (Detroit, MI, USA). Yeast lytic enzyme (80 $000 \mathrm{U} / \mathrm{g}$ ) was obtained from ICN Biochemicals (Costa Mesa, CA, USA). Tunicamycin was obtained from Sigma Chemicals. N-glycosidase $\mathrm{F}$ was obtained from New England BioLabs (Beverly, MA, USA). Pfu thermostable DNA-polymerase and DpnI restriction endonuclease were obtained from Promega (Madison, WI, USA). XL-10 competent Escherichia coli cells were obtained from Stratagene (La Jolla, CA, USA).

The rat D1 antiserum 3049/JL (Leonard et al. 2001), directed against the G-terminus (epitope YEEVRAVLEKLCIPPGHMPQF) was a kind gift of Drs Jack Leonard and Alan Farwell (University of Massachusetts Medical School, Worcester, MA, USA).

\section{Construction of yeast expression vectors}

In order to construct the D1 Cys (SeC126 Cys) and D1 Ser (SeC126 Ser) expression vectors site-directed mutagenesis was used to substitute the SeC (TGA codon) of rat D1 cDNA with Ser (AGG) or Cys (TGG) codons as described (Leonard et al. 2001). The oligonucleotide primers G21A 5'-GCGGGATCCATGG GGCTGTCCCAGCTA and G21B 5'-GGGGGATCC CTAGAAGTGAGGCATGTGTCG (BamHI sites in italics and start/stop codons underlined) were used to PCR amplify the D1 cDNA. The PCR products were 
digested with BamHI and cloned into the BamHI site of the pYES6/CT yeast expression vector. The D1 Cys-His tag expression vector was made by PGR amplification with the oligonucleotide primers G21A and G21BX 5'-GCGTCTAGAGAACTGAGG-CATG TGTCG (XbaI sites in italics). The PGR product was digested with BamHI/XbaI and cloned in the BamHI/XbaI site of pYES6/CT. The D1 Cys-His tag protein contains a 29 amino acid C-terminal extension (SRGPFEGKPIPNPLLGLDSTRTGHHH $\mathrm{HHH}$ ). Amino acid residues 2-35 of D1 encoding the ER signal sequence and the membrane spanning domain (Toyoda et al. 1995b), were deleted via PCR with an oligonucleotide primer spanning codon 1 (ATG) and codons 36-41 of D1 Cys cDNA (G21CB 5'-GGG GGATCCATGAGAGTGAAGCAGAACATC, BamHI in italics and start codon underlined) and the G21BX primer resulting in the D1 Cys- $(\triangle 2-35)$ His-tag expression vector. All constructs were verified by DNA sequencing to ensure that no unwanted mutations were introduced by PCR.

\section{Site-directed mutagenesis of D1Cys}

The D1 Cys expression vector was used as template for site-directed mutagenesis via the circular mutagenesis procedure, followed by selection for mutant plasmids by DpnI digestion (Parikh \& Guengerich 1998, Sambrook \& Russell 2001). Circular mutagenesis was performed with $10 \mathrm{ng}$ plasmid template and $2 \mathrm{U}$ Pfu DNA polymerase. The cycling protocol consisted of $50 \mathrm{~s}$ at $95{ }^{\circ} \mathrm{C}, 50 \mathrm{~s}$ at $60{ }^{\circ} \mathrm{C}$ and $14 \mathrm{~min}$ at $68^{\circ} \mathrm{C}$ for 18 cycles using a Perkin Elmer model 480 cycler. The reaction products were incubated with $10 \mathrm{U}$ DpnI for $2 \mathrm{~h}$ at $37^{\circ} \mathrm{C}$, and transformed into E. coli XL-10 cells. Plasmid DNA isolated from several clones was sequenced to verify that the desired mutation(s) were introduced.

The putative N-linked glycosylation sites (Asn-X-Thr/ Ser) Asn94 and Asn203 were mutated either alone or in combination. The D1 Cys-Asn94 Gln and the D1 CysAsn203 Gln expression vectors were produced using overlapping sense and antisense primers containing the nucleotide changes needed, that is for Asn94 Gln sense 5'GGGCTGGCGCGCGAATGCACGGTGGTCGGC, and for Asn203 Gln sense 5'GTGGACACAATGGAG CAACAGAGGAGGCAGCTC. Mutant codons are underlined. The double mutant D1 Cys-Asn94 Gln/ Asn203 Gln was made using both sets of primers. Four putative phosphorylation sites predicted by the NetPhos server (Blom et al. 1999), that is Ser101, Ser176, Tyr209 and Tyr217 were mutated to Ala and Phe residues respectively. The D1 Cys-Ser101 Ala and D1 CysSer176 Ala expression vectors were produced using overlapping sense and antisense primers containing the nucleotide changes needed, that is for Ser101 Ala sense 5'GTGGTCGGCCTCGCAGGACAGAAGTGCAACG and for Ser176 Ala sense 5'GGCAGCACGGAGCGCT CGAGGACGGCG. The double mutant D1 Cys Ser101 Ala/Ser176 Ala was made using both sets of primers. The D1 Cys-Tyr209 Phe/Tyr217 Phe double mutant expression vector was made using the sense primer 5'CAGGGAGCTCTTTGCAGCTCTGCCTGAGAGG CTCTTTGTGATACA $\mathrm{G}$, and the corresponding antisense primer. The putative N-linked myristoylation site Gly2 (Simon \& Aderem 1992) was mutated to Ala (D1 Cys-G2A) with the sense primer 5' GCTCGGATCGAT GGCGGTGTCGCAGGTATGG, and the corresponding antisense primer.

\section{Yeast transformation, yeast growth conditions and subcellular fractionation}

Transformation was performed by the lithium acetate procedure (Ito et al. 1983), and transformed cells were selected onto synthetic complete $(\mathrm{SC})$ medium plates (Sherman 1991) containing $10 \mu \mathrm{g} / \mathrm{ml}$ blasticidin. After 5 days of incubation at $30^{\circ} \mathrm{C}$ colonies were toothpicked into $5 \mathrm{ml} \mathrm{SC-medium} \mathrm{containing} 10 \mu \mathrm{g} / \mathrm{ml}$ blasticidin and grown overnight at $30^{\circ} \mathrm{C}$. Glycerol stocks $(15 \%$ $\mathrm{vol} / \mathrm{vol}$ glycerol) were made and stored at $-80^{\circ} \mathrm{C}$.

For large scale expression of recombinant $\mathrm{D} 1$ protein, $10 \mathrm{ml} \mathrm{SC}$ medium containing $10 \mu \mathrm{g} / \mathrm{ml}$ blasticidin were inoculated and grown overnight at $30^{\circ} \mathrm{C}$. Expression was induced by inoculating the preculture into 250-500 ml YPG-medium (2\% wt/vol galactose, $1 \%$ $\mathrm{wt} / \mathrm{vol}$ yeast extract, $2 \% \mathrm{wt} / \mathrm{vol}$ bacto-peptone) in a 21 extra deep triple-baffled Erlenmeyer flask (Bellco Glass Inc., Vineland, NJ, USA) and grown for up to $48 \mathrm{~h}$ at $30{ }^{\circ} \mathrm{C}$. The cell density obtained was approx. $0.5 \times 10^{8}$ viable cells $/ \mathrm{ml}$, and more than $80 \%$ of the cells were still blasticidin resistant. Cells were collected by centrifugation, washed with double distilled water and pellets were stored at $-80{ }^{\circ} \mathrm{C}$ until use.

Subcellular fractionation of yeast cells was performed according to established procedures (Franzusoff et al. 1991, Kaiser et al. 2002) with minor modifications. Pellets (from $150-200 \mathrm{ml}$ culture) were resuspended in $15 \mathrm{ml} 10 \mathrm{mM}$ Tris-HCl buffer $(\mathrm{pH} 7 \cdot 5)$ containing $2 \mathrm{M}$ sorbitol, $0 \cdot 1 \mathrm{mM}$ EDTA, $0.4 \mathrm{mM}$ PMSF and $10 \mathrm{mM}$ DTT. After careful resuspension, yeast lytic enzyme was added to a final concentration of $2.5 \mathrm{mg} / \mathrm{ml}$ followed by incubation for $1 \mathrm{~h}$ at $30{ }^{\circ} \mathrm{C}$. Spheroplasts were collected by centrifugation for $10 \mathrm{~min}$ at $120 \mathrm{~g}$, washed with icecold $10 \mathrm{mM}$ Tris- $\mathrm{HCl}$ buffer $(\mathrm{pH} 7 \cdot 5)$ containing $0.65 \mathrm{M}$ sorbitol, $1 \mathrm{mM}$ DTT, $0.1 \mathrm{mM}$ EDTA and $0.4 \mathrm{mM}$ PMSF, and resuspended in $15 \mathrm{ml}$ of the same cold buffer. Spheroplasts were lyzed by sonification using 4-6 bursts (15 s each) with a $3 \mathrm{~mm}$ probe of a Sanyo Soniprep 150 Ultrasonic disintegrator at an amplitude setting of 10 microns. The sonicated suspension was centrifuged for $30 \mathrm{~min}$ at $1000 \boldsymbol{g}$ in the cold and the supernatant (= crude homogenate) was centrifuged for 
$30 \mathrm{~min}$ at $10000 \mathrm{~g}$ and $8{ }^{\circ} \mathrm{C}$. The $10000 \boldsymbol{g}$ supernatant was centrifuged for $90 \mathrm{~min}$ at $100000 \mathrm{~g}$ and $8{ }^{\circ} \mathrm{C}$. The $10000 \boldsymbol{g}$ and $100000 \boldsymbol{g}$ pellets where resuspended in $100 \mathrm{mM}$ phosphate $\mathrm{pH} 7 \cdot 2,2 \mathrm{mM}$ EDTA, $1 \mathrm{mM}$ DTT buffer and stored in aliquots at $-80^{\circ} \mathrm{C}$.

For equilibrium sedimentation experiments, yeast cells were broken by agitation with glass beads in $10 \mathrm{mM}$ Tris- $\mathrm{HCl}(\mathrm{pH} 7.5)$ buffer containing 10\% wt/wt sucrose and $10 \mathrm{mM}$ EDTA (Kaiser et al. 2002). The homogenates were centrifuged for $5 \mathrm{~min}$ at $500 \boldsymbol{g}$, and the supernatant was loaded on $20 \% \mathrm{wt} / \mathrm{wt}-60 \% \mathrm{wt} / \mathrm{wt}$ sucrose-density gradients in $10 \mathrm{mM}$ Tris- $\mathrm{HCl}(\mathrm{pH} 7 \cdot 5)$, $10 \mathrm{mM}$ EDTA buffer. The gradients were run for $16 \mathrm{~h}$ at 32000 r.p.m. $(100000 \mathrm{~g})$ in an SW60 rotor at $8{ }^{\circ} \mathrm{C}$. Fractions of $0.3 \mathrm{ml}$ were collected from the top and stored at $-80^{\circ} \mathrm{C}$.

\section{Deiodinase enzyme activity assay}

The principle of this assay is the production of radioiodide by ORD of $\left[3^{\prime}, 5^{\prime}-125 \Pi \mathrm{rT} 3\right.$. Incubation mixtures contained about 100000 c.p.m. ${ }^{125}$ I-rT3 with or without varying concentrations of unlabeled substrate (rT3, T4 or T3) and varying amounts of yeast subcellular fractions or rat liver microsomes in $200 \mu \mathrm{l}$ P100E2D10 (100 mM phosphate, $2 \mathrm{mM}$ EDTA, $10 \mathrm{mM}$ DTT, pH 7.2). In some experiments deiodinase inhibitors (PTU, IAc) were included. Mixtures were incubated in duplicate for $10-60 \mathrm{~min}$ at $37^{\circ} \mathrm{C}$, and the reactions were stopped by addition of $100 \mu \mathrm{l} 5 \% \mathrm{BSA}$ on ice. Protein-bound iodothyronines were precipitated by addition of $500 \mu \mathrm{l} 10 \%$ trichloroacetic acid, and the radioiodide in the supernatant was separated from remaining iodothyronines by chromatography on Sephadex LH-20 columns as described by Eelkman et al. (1987). Blank incubations without enzyme were used to correct for nonenzymatic deiodination $(<3 \%$ of total deiodination). Protein was adjusted in order to consume less than $30 \%$ of the substrate, and it was determined that the deiodination rate was linear up to $60 \mathrm{~min}$ incubation. The ${ }^{125} \mathrm{I}^{-}$production was multiplied by 2 to account for the random labeling and deiodination of the $3^{\prime}$ and $5^{\prime}$ positions in $\mathrm{rT} 3$.

\section{Affinity-labeling with $\mathrm{N}$-bromoacetyl-[125I]T3}

Solutions of $\mathrm{BrAc}\left[{ }^{125}\right] \mathrm{T} 3$ (100 000 c.p.m.) in ethanol were pipetted into microcentrifuge tubes and the solvent was evaporated under a stream of nitrogen. After the addition of $25 \mu \mathrm{l} \mathrm{P100E2D10} \mathrm{buffer} \mathrm{and} \mathrm{vortexing} \mathrm{for}$ $10 \mathrm{~s}$, protein fractions $(50-100 \mu \mathrm{g})$ were added in a total volume of $50 \mu \mathrm{l} \mathrm{P100E2D10} \mathrm{buffer.} \mathrm{Again} \mathrm{the} \mathrm{mixtures}$ were vortexed, and incubated for $15 \mathrm{~min}$ at $37^{\circ} \mathrm{C}$. The reaction was stopped by the addition of $25 \mu \mathrm{l} 4 \times$ concentrated SDS-PAGE sample buffer containing $40 \mathrm{mM}$ DTT. After incubation for $5 \mathrm{~min}$ at $80^{\circ} \mathrm{C}$, the samples were loaded on a 12\% SDS-PAGE gel and run overnight. Gels were stained with Coomassie brilliant blue R-250, dried under vacuum and autoradiographed for $16-24 \mathrm{~h}$.

The D1 Cys protein content of yeast microsomal fractions was determined as described (Berry et al. 1992, Schoenmakers et al. 1992) by saturation analysis of the Dl protein labeling in the presence of a fixed amount of $\mathrm{BrAc}\left[{ }^{125}\right] \mathrm{T} 3$ and increasing concentrations of nonradioactive BrAcT3, assuming that one molecule of $\mathrm{D} 1$ protein binds one molecule of BrAcT3.

\section{Western blot of D1 protein}

Homogenates or subcellular fractions $(50-100 \mu \mathrm{g}$ protein) were mixed with sample buffer (final concentration $40 \mathrm{mM}$ Tris $\mathrm{HCl}, \mathrm{pH} 6 \cdot 8,5 \% \mathrm{vol} / \mathrm{vol}$ glycerol, $2 \% \mathrm{wt} / \mathrm{vol}$ SDS and $10 \mathrm{mM}$ DTT), heated for $5 \mathrm{~min}$ at $80{ }^{\circ} \mathrm{C}$ and centrifuged $(10000 \mathrm{~g})$. The supernatants were separated on $12 \%$ SDS-PAGE gels in the Protean II mini-gel system (Bio-Rad), according to the manufacturer's instructions. After electrophoresis, the gels were positioned on nitrocellulose paper (Hybond C-pure, Amersham Pharmacia Biotech) and placed in a Bio-Rad mini Trans blot cell filled with buffer $(25 \mathrm{mM}$ Tris $\mathrm{HCl}$, pH $8.3,160 \mathrm{mM}$ glycine and $20 \% \mathrm{vol} / \mathrm{vol}$ methanol). The transfer was performed for $60 \mathrm{~min}$ at $100 \mathrm{~V}$. After blotting, the paper was blocked overnight in $10 \%$ wt/vol non-fat milk powder in PBS/ $0.1 \% \mathrm{vol} / \mathrm{vol}$ Tween 20 (PBS-Tween). Thereafter, the blot was incubated with a 1:1000 dilution of the $\mathrm{D} 1$ antiserum in $10 \%$ milk-PBS-Tween for $2 \mathrm{~h}$ up to overnight. After washing $(2 \times 15 \mathrm{~min}$ in $10 \%$ milk-PBS-Tween and $2 \times 15$ min in PBS-Tween), the blot was incubated with peroxidase-conjugated anti-rabbit IgG diluted 1:25000 in $10 \%$ milk-PBS-Tween. After washing in the same way as described above, the reaction products were visualized with a home-made chemiluminescence system (Schneppenheim et al. 1991) consisting of $0.7 \mu \mathrm{M}$ p-coumaric acid, $1.25 \mathrm{mM}$ luminol, $0.01 \%$ hydrogen peroxide in $0.1 \mathrm{M}$ Tris $\mathrm{HCl}, \mathrm{pH} 8.5$ and exposure to Kodak Biomax MS film.

\section{Analysis of D1Cys post-translational modification}

The antibiotic tunicamycin prevents the N-linked glycosylation and/or S-linked palmitoylation of proteins in eukaryotic cells (Orlean et al. 1991, Patterson \& Pate Skene 1995). Tunicamycin was dissolved in a minimum amount of $1 \mathrm{M} \mathrm{NaOH}$ and diluted to a final concentration of $1 \mathrm{mg} / \mathrm{ml}$ with bidest. This stock solution was stored at $-20{ }^{\circ} \mathrm{C}$. Yeast cells were grown overnight at $30^{\circ} \mathrm{C}$ in YPG medium or SC medium with up to $5 \mu \mathrm{g} / \mathrm{ml}$ tunicamycin. After homogenization, the $1000 \mathrm{~g}$ supernatant fraction was prepared and D1 protein labeled with $\mathrm{BrAc}\left[{ }^{125} \Pi \mathrm{T} 3\right.$ as described. 
$\mathrm{N}$-glycosidase $\mathrm{F}$ cleaves between the innermost $\mathrm{N}$-acetylglucosamine and asparagine residues of high mannose, hybrid, and complex oligosaccharides from N-linked glycoproteins (Orlean et al. 1991). For deglycosylation experiments, the D1 Cys protein in microsomal fractions was labeled with $\mathrm{BrAc}\left[{ }^{125} \mathrm{~T}\right] 3$ and immunoprecipitated with the $3049 \mathrm{D} 1$ antiserum as described (Leonard et al. 2001). The purified D1 protein was incubated with $1000 \mathrm{U} \mathrm{N}$-glycosidase $\mathrm{F}$ at $37^{\circ} \mathrm{C}$ overnight in $50 \mathrm{mM}$ sodium phosphate buffer $(\mathrm{pH} 7 \cdot 5)$, 0.5\% SDS, $1 \%$ mercaptoethanol and 1\% NP-40.

Palmitoylated proteins are S-acetylated by attachment of palmitate via a thioester linkage to the sulfydryl group of cysteine, and this linkage is cleaved by treatment with hydroxyl amine (Liang et al. 2002). The D1 Gys protein in microsomal fractions was labeled with $\mathrm{BrAc}\left[{ }^{125} \Pi \mathrm{T} 3\right.$ and thereafter incubated for $4 \mathrm{~h}$ with $1 \mathrm{M}$ hydroxyl amine ( $\mathrm{pH}$ 8).

\section{Results}

\section{Kinetic analysis of D1 activity in yeast subcellular fractions}

The D1 Cys and D1 Ser cDNAs were cloned in the yeast expression vector pYES6. In this system proteins are expressed under the control of the GAL1 promoter, allowing propagation of transformed cells in medium with a noninducing carbon source (glucose) and subsequent induction by the addition of galactose (Guengerich et al. 1991). An important feature of this system is the possibility to use different galactose induction times in order to avoid saturation of the cell's protein folding capacity (Griffith et al. 2003).

After induction (16 h), microsomal fractions $(100000 \boldsymbol{g}$ pellet $)$ were isolated from yeast cells harboring pYES6 (control yeast), pYES6-D1 Gys or pYES6-D1 Ser. The kinetic characteristics of the D1 Cys protein in yeast microsomal fractions were compared with those of the native $\mathrm{D} 1$ protein in rat liver microsomal fractions. Incubations in the presence of increasing concentrations $(0 \cdot 1-10 \mu \mathrm{M})$ of $\mathrm{rT} 3, \mathrm{~T} 3$ and $\mathrm{T} 4$ resulted in the progressive inhibition of the ORD of $10 \mathrm{nM}\left[{ }^{125} \mathrm{n}\right] \mathrm{rT} 3$ by D1 Cys and native D1 protein (Fig. 1A). The potencies by which the different iodothyronines inhibited the ORD of $\left[{ }^{125} \mathrm{I}\right] \mathrm{rT} 3$ decreased in the order $\mathrm{rT} 3>\mathrm{T} 4>\mathrm{T} 3$ for native $\mathrm{D} 1$ protein and $\mathrm{rT} 3=\mathrm{T} 4>\mathrm{T} 3$ for $\mathrm{D} 1 \mathrm{Cys}$ protein. The $\mathrm{IC}_{50}$ values were $0.5 \mu \mathrm{M}$ rT3, $3 \mu \mathrm{M} \mathrm{T} 4$ and $>10 \mu \mathrm{M}$ T3 for native $\mathrm{D} 1$ protein and approximately $3 \mu \mathrm{M}$ rT3, $3 \mu \mathrm{M} \mathrm{T} 4$ and $>10 \mu \mathrm{M}$ T3 for D1 Cys protein. The apparent $K_{\mathrm{m}}$ (Michaelis-Menten constant) for rT3 ORD was $2 \cdot 6 \mu \mathrm{M}(n=3)$ for the D1 Cys protein and $0.2 \mu \mathrm{M}(n=2)$ for the native $\mathrm{D} 1$ protein (Fig. 1B), while the $V_{\max }$ of the D1 Cys protein fraction was about half of that for the rat liver microsomal fraction ( $400 \mathrm{vs} 850 \mathrm{pmol} \mathrm{rT} 3 / \mathrm{min} / \mathrm{mg}$ ). No significant deiodinase activity was present in microsomal fractions from yeast cells expressing D1 Ser protein or from control yeast cells.

ORD of rT3 or T4 by the D1 selenoprotein exhibits ping-pong kinetics with the iodothyronine and thiolcontaining cofactor as cosubstrates (Visser 1980, Hennemann \& Visser 1997). The selenol group (SeH) of the native enzyme is thought to be converted by reaction with rT3 into a selenenyl iodide (SeI) intermediate, which is converted back to the native enzyme by reaction with cofactor (DTT in vitro). The D1 inhibitors PTU (6-propyl-2-thiouracil) and IAc (iodoacetate) interact with the $\mathrm{SeC}$ residue, either with the SeI intermediate or the native $\mathrm{SeH}$ respectively. Keeping this in mind, it is not surprising that replacing the $\mathrm{SeC}$ residue by Cys $(\mathrm{SeH}$ to $\mathrm{SH})$ reduces the sensitivity of $\mathrm{D} 1$ for PTU and IAc (Fig. 1C). In fact, the D1 Cys protein was essentially insensitive to the addition of PTU

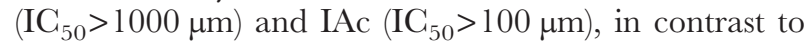
the marked inhibition of the $\mathrm{Dl}$ protein in rat liver microsomes $\left(\mathrm{PTU} \mathrm{IC}_{50}=1 \mu \mathrm{M}\right.$ and $\left.\mathrm{IAc}_{\mathrm{IC}_{50}}=2 \mu \mathrm{M}\right)$.

IRD activity of D 1 Cys protein was minimal. No significant deiodination of T3 could be detected, whereas with T3 sulfate (T3S) as substrate some IRD activity could be measured $\left(K_{\mathrm{m}} 2 \mu \mathrm{M}, \mathrm{V}_{\max } 8 \mathrm{pmol} /\right.$ $\left.\mathrm{min} / \mathrm{mg}, \mathrm{V}_{\max } / K_{\mathrm{m}} 4\right)$. In comparison, the IRD of T3S by $\mathrm{D} 1$ protein in rat liver microsomes is more efficient $\left(K_{\mathrm{m}} 4 \mu \mathrm{M}\right.$ and $\left.\mathrm{V}_{\max } 1000 \mathrm{pmol} / \mathrm{min} / \mathrm{mg}, \mathrm{V}_{\max } / K_{\mathrm{m}} 250\right)$ (Visser et al. 1983).

The thyroid hormone derivative $\mathcal{N}$-bromoacetyl-T3 (BrAcT3) acts as an irreversible active site-directed inhibitor of $\mathrm{D} 1$ protein (Mol et al. 1984). Despite the SeC to Cys substitution, BrAcT3 strongly inhibited the ORD of rT3 by both the D1 Cys protein and the native D1 (D1 SeC) protein (Fig. 1C). The $\mathrm{IC}_{50}$ value was about tenfold higher for the D1 Cys protein than for the native D1 protein ( 50 vs $5 \mathrm{nM}$ ).

In order to enable future purification by metalchelation affinity-chromatography, the D1 Cys protein was also expressed with a C-terminal poly-His-tag (D1 Cys-His-tag). This affinity tag consists of 6 His residues and a linker of 23 amino acid residues (see Materials and methods). The kinetic characteristics of the D1 Cys-His-tag protein were essentially the same as those of the D1 Cys protein $\left(K_{\mathrm{m}}\right.$ rT3 $2 \cdot 1 \mu \mathrm{M}$ and $\mathrm{V}_{\max }$ $250 \mathrm{pmol} / \mathrm{min} / \mathrm{mg}$ ).

For evaluation of the subcellular localization of the D1 Cys protein in yeast cells, fractionation experiments were performed using sequential centrifugations (Fekkes et al. 1979, Kaiser et al. 2002). Both the $10000 \mathrm{~g}$ and the $100000 \boldsymbol{g}$ membrane pellets were enriched in deiodinase activity compared with the $1000 \boldsymbol{g}$ supernatant and the cytosolic fraction, indicating that the D1 Gys and D1 Cys-His-tag proteins are membrane associated in yeast cells (Fig. 1D). It should be realized that during yeast 
(A)

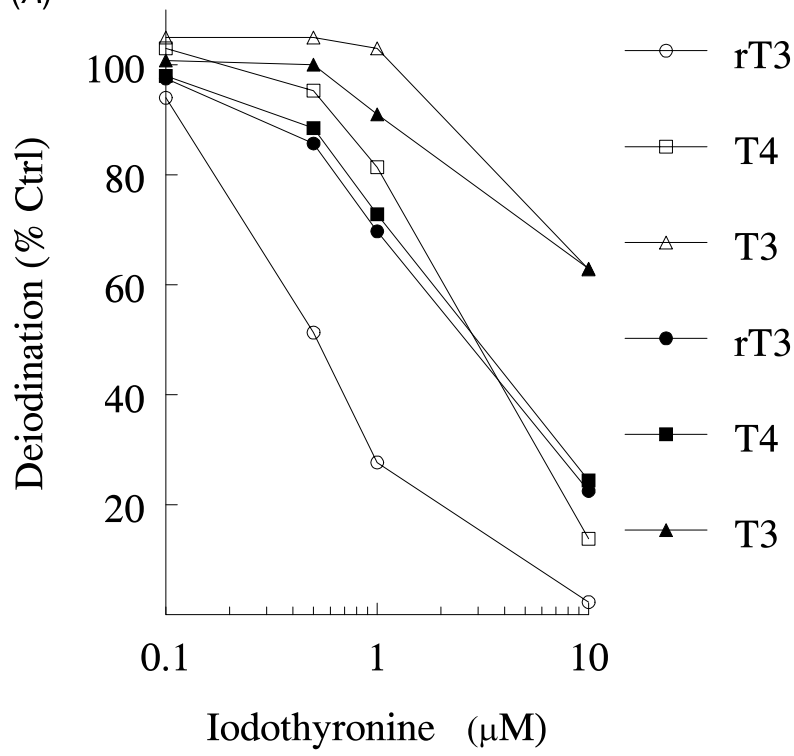

(C)

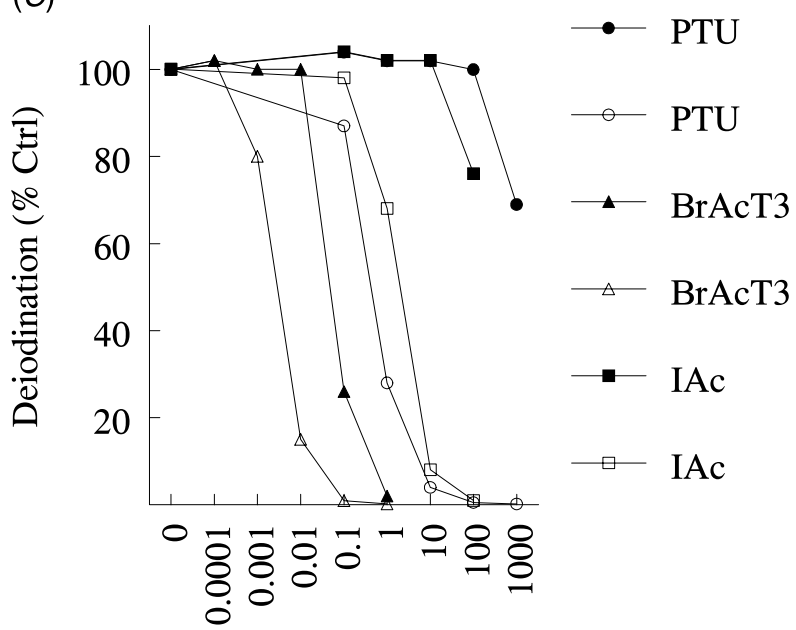

(B)

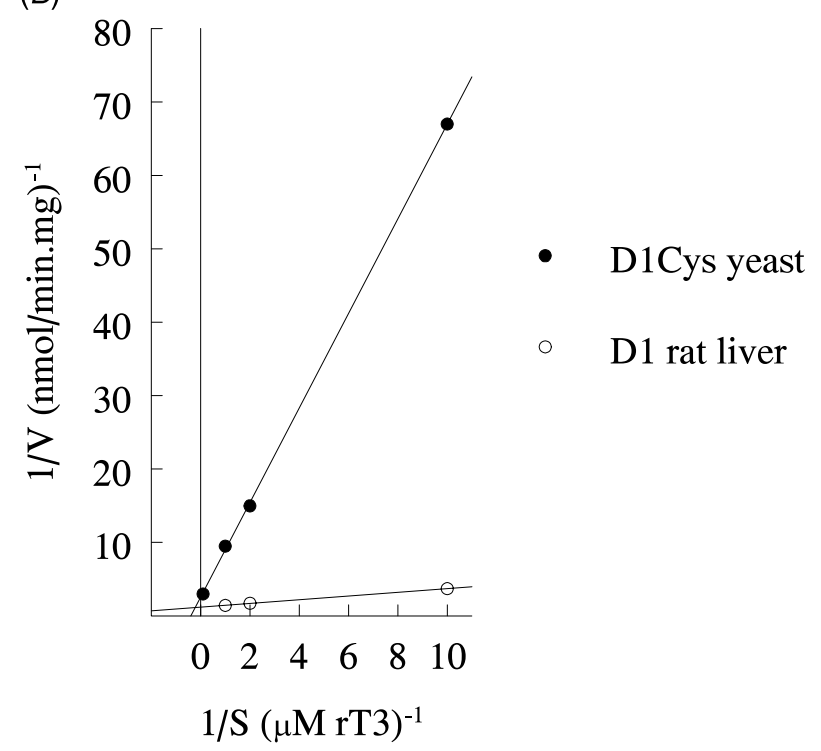

$(D)$

\section{Inhibitor $(\mu \mathrm{M})$}

Figure 1 Kinetic characterization and subcellular distribution of D1 Cys protein. (A) ORD of rT3 (10 nM 125I-rT3) by rat D1 protein (open symbols) and yeast D1 Cys protein (closed symbols). Rat liver microsomes (5 $\mathrm{\mu g}$ protein/ml) and yeast microsomes $(40 \mu \mathrm{g} / \mathrm{ml})$ were incubated for $60 \mathrm{~min}$ at $37^{\circ} \mathrm{C}$ in the presence of the indicated iodothyronine concentrations. (B) Double reciprocal plot of ORD of rT3 by microsomal fractions prepared from rat liver (D1 enzyme, open symbols) or from yeast (D1 Cys, closed symbols). The $K_{\mathrm{m}}$ and $\mathrm{V}_{\max }$ values are $0.21 \mu \mathrm{M}$ and $850 \mathrm{pmol} / \mathrm{min} / \mathrm{mg}$ respectively for rat D1, and $2.6 \mu \mathrm{M}$ and $400 \mathrm{pmol} / \mathrm{min} / \mathrm{mg}$ respectively for D1 Cys protein. (C) Inhibition of rT3 ORD (100 nM 125/-rT3) of rat liver D1 (open symbols) or D1 Cys (closed symbols) by PTU, IAc or BrAcT3. (D) Subcellular fractionation of yeast cells expressing D1 Cys protein (solid bars) or D1 Cys-His-tag protein (open bars). The rT3 ORD activity (100 nM 125I-rT3) was measured in fractions A (1000 × $g$ supernatant), B $(10000 \times \boldsymbol{g}$ pellet $), \mathrm{C}(100000 \times \boldsymbol{g}$ pellet $)$ and $\mathrm{D}(100000 \times \boldsymbol{g}$ supernatant). Ctrl, control.

cell fractionation the plasma membranes are recovered almost entirely in the $10000 \mathrm{~g}$ pellet, while the endoplasmic reticulum (ER) and Golgi complex are both divided between the $10000 \boldsymbol{g}$ and $100000 \boldsymbol{g}$ membrane fractions (Franzusoff et al. 1991). The possible location of D1 Cys protein in the plasma membrane was investigated by sucrose-density gradient centifugation (see next section under affinity labeling).

In an attempt to produce a soluble form of the D1 Cys protein, an expression vector was made in which the transmembrane domain (amino acid residues 2-35) was deleted. However, no deiodinase activity could be 

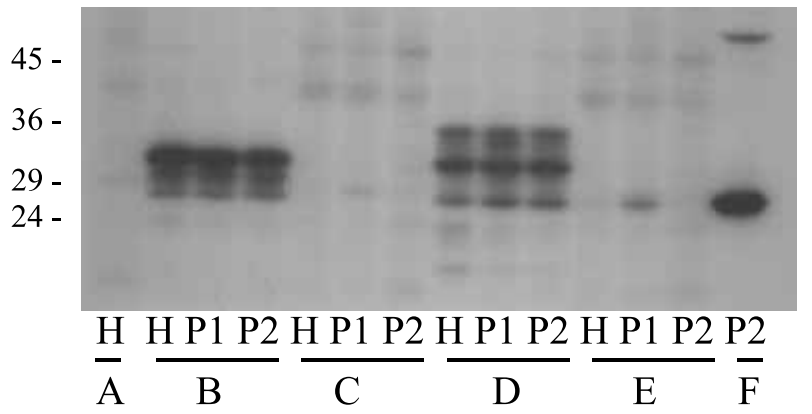

Figure 2 Affinity-labeling of D1 Cys protein with $\mathrm{BrAc}\left[{ }^{125} \mathrm{I}\right] \mathrm{T3}$. Labeling patterns obtained by SDS-PAGE and autoradiography after reaction of yeast homogenates $(\mathrm{H}), 10000 \mathrm{~g}$ pellets $(\mathrm{P} 1)$ or $100000 \mathrm{~g}$ pellets (P2) containing no recombinant protein (A), D1 Cys (B), D1 Ser (C), D1 Cys-His-tag (D), D1 Cys $(\triangle 2-35)$ His-tag $(E)$ or rat liver D1 protein $(F)$ with $\mathrm{BrAc}\left[{ }^{125} \mid\right] \mathrm{T} 3$. Migration distances of molecular mass markers (kilodaltons) are indicated.

measured in any subcellular fraction prepared from yeast cells expressing the D1 Cys $(\triangle 2-35)$ His-tag protein.

\section{Affinity-labeling of D1 protein with $\operatorname{BrAc}\left[{ }^{125}\right] \mathrm{T} 3$}

As already described, BrAcT3 inhibited the ORD of rT3 by D1 Cys protein, indicating interaction of BrAcT3 with the D1 Cys protein. It was therefore decided to produce $\mathrm{BrAc}\left[{ }^{125} \mathrm{~T}\right] 3$ and to analyze the affinitylabeling of yeast subcellular fractions.

In Fig. 2 a typical example is shown of the labeling patterns obtained after reaction of $\operatorname{BrAc}\left[{ }^{125} \Gamma\right] \mathrm{T} 3$ with rat liver microsomes or yeast subcellular fractions. Using rat liver microsomes the protein band with an apparent molecular mass of $27 \mathrm{kDa}$ represents $\mathrm{Dl}$ protein (Schoenmakers et al. 1992), while the more weakly labeled protein band of $56 \mathrm{kDa}$ represents protein disulfide isomerase (Schoenmakers et al. 1989). Using D1 Cys-containing fractions several isoforms (at least 3) with apparent molecular masses between 27 and $32 \mathrm{kDa}$ are

( $A)$

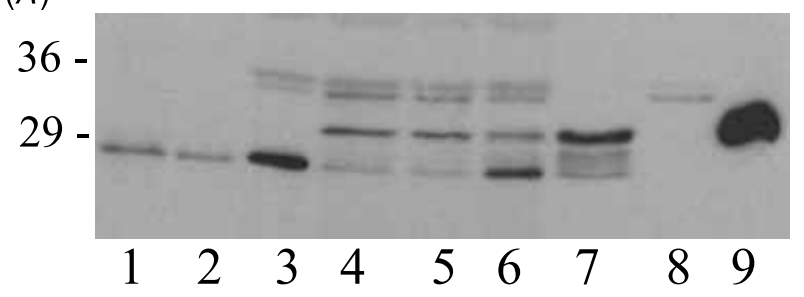

present, of which the $32 \mathrm{kDa}$ band is the most strongly labeled. The increased apparent molecular mass of the D1 Cys protein in yeast fractions compared with the D1 protein in rat liver microsomes might reflect unique posttranslational modifications of $\mathrm{D} 1$ protein in yeast. It is known that post-translational modifications such as phosphorylation, glycosylation and acylation of proteins can result in so called 'upshifts' in apparent molecular mass during SDS-PAGE (Halligan et al. 2004, Wong et al. 2004). The Dl Cys-His-tag protein was detected as several isoforms after affinity-labeling (at least 3) with apparent molecular masses between 27-34 kDa (Fig. 2). In subcellular fractions of yeast expressing the D1 Ser or D1 Cys $(\triangle 2-35)$ His-tag protein, either no or only a faintly labeled protein around $27 \mathrm{kDa}$ was detected. The fact that in microsomal fractions (100 $000 \boldsymbol{g}$ pellet) from yeast cells expressing these proteins there was also no deiodinase activity measured could be explained by improper folding/processing or the absence of an essential domain.

Immunoblots (Fig. 3) were made using a rabbit antiserum directed against the C-terminus of the rat D1 protein (see Materials and methods). The D1 antibody recognized a single protein with an apparent molecular mass of $27 \mathrm{kDa}$ in rat liver microsomes. In contrast, the D1 Cys protein from yeast microsomes migrated as four protein isoforms between 27 and $32 \mathrm{kDa}$. Microsomes containing D1 Cys-His-tag revealed protein isoforms between 27 and $34 \mathrm{kDa}$. For native and recombinant D1 similar isoform patterns were obtained after affinitylabeling and immunoblotting (Figs 2 and 3). Immunoblot analysis clearly proved the expression of the D1 Cys $(\triangle 2-35)$ His-tag protein (single $27 \mathrm{kDa}$ protein) and D1 Ser as several protein isoforms between 27 and $32 \mathrm{kDa}$ (Fig. 3). Immunoblot analysis with an anti-Histag antiserum proved the presence of the His-tag in D1 Cys $(\triangle 2-35)$ His-tag protein (not shown). Obviously, the post-translational modification(s) of the Dl Cys $(\triangle 2$ 35)His-tag and D1 Ser proteins are different from those of the D1 Cys protein (Fig. 3). Immunoblot analysis of

(B)

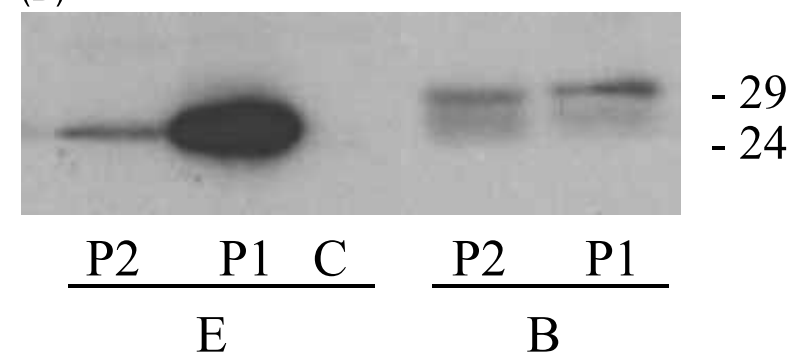

Figure 3 Immunoblot of D1 Cys protein. (A) Immunoblots of microsomal fractions (100 $000 \mathrm{~g}$ pellets) made from rat liver (lane 1 and 2) or yeast cells expressing D1 Cys( $\triangle 2-35)$ His-tag (lane 3), D1 Cys-His-tag (lanes 4 and 5), D1 Ser (lane 6), and D1 Cys (lane 7) protein. Control yeast cells (lane 8) and E. coli-expressed D1 Cys-His-tag protein (lane 9) are also included. (B) Immunoblots of $10000 \mathrm{~g}$ pellet (P1), $100000 \mathrm{~g}$ pellet (P2) and cytosolic fractions (C) containing D1 Cys $(\triangle 2-35) H i s-t a g$ protein (E) or D1 Cys protein (B). 


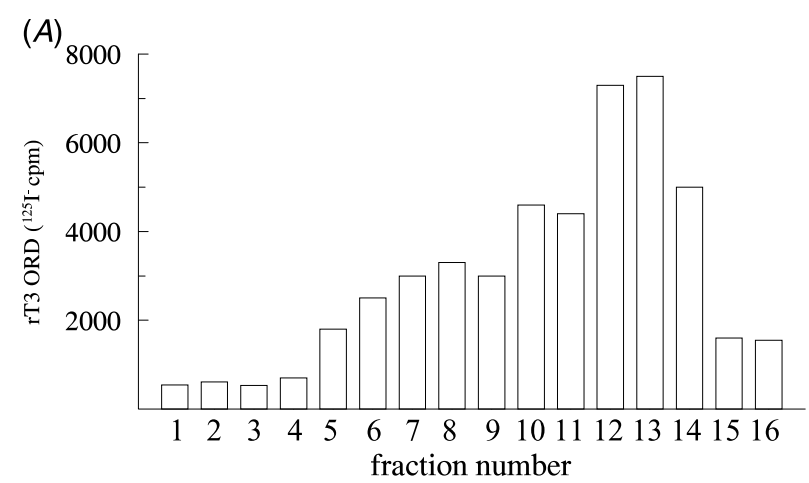

(B)

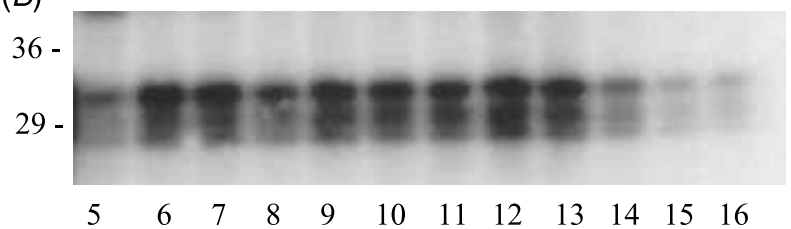

Figure 4 Sucrose-density gradient centrifugation of yeast homogenate containing D1 Cys protein. (A) ORD activity from $10 \%$ of each fraction (fraction $1=$ top and fraction $16=$ bottom) with $100 \mathrm{nM}$ 125I-rT3 in P100E2D10 buffer. (B) Labeling pattern obtained after incubation of $15 \%$ of each fraction with $\operatorname{BrAc}\left[{ }^{125}\right]$ T3 and SDS-PAGE.

the subcellular fractions revealed that the D1 Cys $\triangle 2$ 35)His-tag protein is predominantly present in the $10000 \boldsymbol{g}$ pellet, whereas the D1 Cys protein is more equally distributed over the $10000 \boldsymbol{g}$ and $100000 \boldsymbol{g}$ membrane fractions (Fig. 3B). In the cytosolic extracts no D1 Gys nor D1 Gys $(\triangle 2-35)$ His-tag could be detected. For comparison, the D1 Cys-His-tag protein expressed in E. coli (inclusion bodies) is included on the Western blot (Fig. 3A lane 9).

The D1 content of D1 Cys and D1 Cys-His-tag microsomal fractions was determined by saturation analysis of progressive labeling of the proteins in the $27-34 \mathrm{kDa}$ bands with increasing concentrations of unlabeled BrAcT3 as described previously (Berry et al. 1992, Schoenmakers et al. 1992). The Dl content thus calculated is $65 \mathrm{pmol} / \mathrm{mg}$ protein and together with the $\mathrm{V}_{\max }$ for ORD of rT3 of this preparation (250 pmol/ $\mathrm{min} / \mathrm{mg}$ ), this results in a substrate turnover number of about $4 / \mathrm{min}$.

Fractionation by equilibrium sedimentation is a suitable method for identifying proteins that are located in either the ER or the plasma membranes. The plasma membranes are of relatively high density and under appropiate conditions they can be resolved from the relatively less dense membranes derived from the ER and Golgi complex (Kaiser et al. 2002). Sucrose-density gradients were run (see Materials and methods) and the fractions were analyzed by rT3 deiodination assays as well as by affinity-labeling with $\mathrm{BrAc}\left[{ }^{125} \mathrm{~T}\right.$ T3 (Fig. 4).
Relatively high levels of activity were found in fractions 12 and 13 (fraction $1=$ top, fraction $16=$ bottom), while in fractions $6-10$ intermediate levels of activity were found (Fig. 4A). The plasma membranes are present in fractions 12 - 14, while the ER and Golgi complex membranes are divided over fractions 6-10 (Kaiser et al. 2002). With regard to plasma membranes this was confirmed since SDS-PAGE showed the presence of the $100 \mathrm{kDa}$ Pmalp plasma membrane $\mathrm{H}^{+}$-ATPase protein (Hasper et al. 1999) in fractions $12-14$ (not shown). The presence of D1 Cys protein (27 - $32 \mathrm{kDa}$ isoforms) in plasma membrane as well as in the ER and Golgi complex was confirmed by $\mathrm{BrAc}\left[{ }^{125}\right] \mathrm{T} 3$ labeling of the fractions (Fig. 4B).

\section{Post-translational modification of D1 protein in yeast}

Galactose-induced D1 Cys protein-expressing yeast cells were harvested at different time points $(4,6,8,24,32$ and $52 \mathrm{~h}$ ), and lyzates were analyzed by ${ }^{125} \mathrm{I}$-BrAcT3 labeling. From $6 \mathrm{~h}$ onwards the Dl Cys protein was detectable, and reached optimum levels at $24-32 \mathrm{~h}$. At each time point the described three isoforms with apparent molecular masses from 27 to $32 \mathrm{kDa}$ were present and the $32 \mathrm{kDa}$ isoform was the most prominent (results not shown).

Many membrane and secretory proteins are glycoproteins, and yeast adds N-linked and/or O-linked oligosaccharides to glycoproteins (Orlean et al. 1991, Gemmill \& Trimble 1999). The N-linked oligosaccharides are added co-translationally in the ER to asparagine residues within the consensus sequence Asn-X-Ser/Thr. The rat D1 protein contains two potential N-linked glycosylation sites at Asn residues 94 and 203. Therefore, we initially focussed on the possibility of N-linked glycosylation as an explanation for the observed heterogeneity of $\mathrm{D} 1$ protein. Tunicamycin is an inhibitor of N-linked glycosylation (Orlean et al. 1991). Yeast cells expressing the D1 Cys protein were grown overnight in the presence of tunicamycin, and after homogenization the $\mathrm{D} 1$ protein was labeled with $\mathrm{BrAc}\left[{ }^{125}\right] \mathrm{T} 3$. No change in the $27-32 \mathrm{kDa}$ isoform pattern was observed (not shown). However, incubation with tunicamycin dose-dependently reduced the growth of yeast cells in YPD medium (about 15-fold reduction in OD600 at $5 \mu \mathrm{g}$ tunicamycin/ml). Due to the toxicity of tunicamycin it was not possible to increase the concentration further. Incubation of the D1 Cys protein with $\mathrm{N}$-glycosidase $\mathrm{F}$ (see Materials and methods) did not result in changes in the $27-32 \mathrm{kDa}$ isoform pattern either (not shown).

Since these experiments were inconclusive it was decided to mutate the potential N-linked glycosylation sites at asparagine residues 94 and 203. At this point, the possibility of alternative post-translational modifications was taken into consideration by site-directed 
mutagenesis of potential phosphorylation sites (Blom et al. 1999) at serine residues 176 (casein kinase II site), serine residue 101 (protein kinase A), tyrosine residues 209 and 217 (tyrosine kinase sites) and a potential N-myristoylation site (Utsumi et al. 2001) at glycine residue 2 .

None of these mutations caused complete reversal of the $27-32 \mathrm{kDa}$ isoform pattern, indicating that $\mathrm{N}$-linked glycosylation, myristoylation or phosphorylation at the indicated sites alone are not the source of the observed heterogeneity (Fig. 5). Some minor, but reproducible changes were observed. In the case of the D1 Cys-Tyr209 Phe/Tyr217 Phe double mutant protein the isoform pattern as a whole was downshifted to lower apparent molecular masses. This suggests phosphorylation of Tyr residues 209 and/or 217 in all D1 Cys isoforms, including the $27 \mathrm{kDa}$ isoform. Remarkably, for the Gly2 Ala mutant protein (removing a potential $\mathrm{N}$-myristoylation site) the isoform pattern as such was preserved but the labeling pattern was reversed in the sense that the lower $27 \mathrm{kDa}$ protein isoform was now most strongly labeled. This change in isoform pattern (confirmed by Western blotting, see Fig. 5C) suggests (partial) myristoylation of D1 Cys protein at glycine residue 2 or altered targetting of the D1 CysGly2 Ala protein, thereby influencing another posttranslational modification(s). N-myristoylation and/or S-palmitoylation are required for plasma membrane targeting of various proteins, for instance heterotrimeric G-protein subunits (Manahan et al. 2000, Chen \& Manning 2001). In the case of palmitoylation, the 16-carbon fatty acid chain is attached via a thioester linkage to cysteine residues, while in the case of myristoylation the 14-carbon fatty acid chain is attached via an amide linkage to an amino-terminal glycine residue. Palmitoylation is sensitive to treatment with hydroxyl amine, while myristoylation is not (Manahan et al. 2000). Treatment with hydroxyl amine (see Materials and methods) did not change the isoform pattern during SDS-PAGE, thereby excluding palmitoylation of D1 Cys protein as the cause of the observed heterogeneity (not shown).

The kinetic characteristics of the mutant D1 Cys proteins were determined (Table 1 and Fig. 6A and B). Especially, the double mutant proteins, i.e. D1 Cys-Asn94 Gln/Asn203 Gln, D1 Cys-Ser101 Ala/ Ser176 Ala and D1 Cys-Tyr209 Phe/Tyr217 Phe had significantly reduced enzyme activity as reflected in increased $K_{\mathrm{m}}$ values and/or decreased $\mathrm{V}_{\max }$ values. The kinetic characteristics of the D1 Cys-Gly2 Ala protein are similar to those of the D1 Cys and D1 Cys-His tag protein. As already stated, myristoylation at glycine residue 2 is required for plasma membrane targeting of various proteins, for instance heterotrimeric G-protein subunits (Manahan et al. 2000). Upon subcellular fractionation of yeast cells the distribution of the D1 Cys
$(A)$

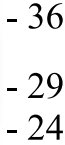

\section{$\begin{array}{llllllllllllll}1 & 2 & 3 & 4 & 5 & 6 & 7 & 8 & 9 & 10 & 11 & 12 & 13\end{array}$}

(B)

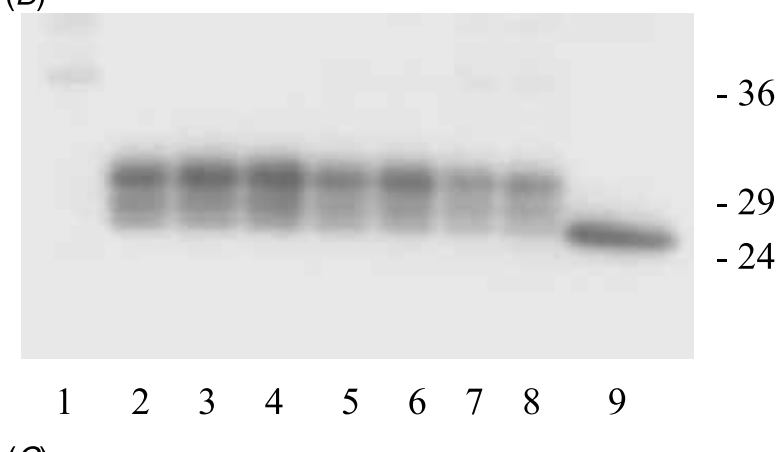

(C)

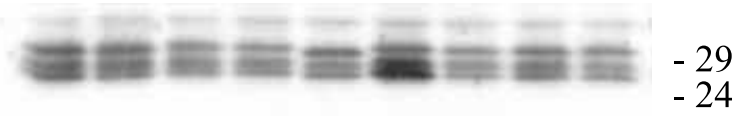

\section{$\begin{array}{lllllllll}1 & 2 & 3 & 4 & 5 & 6 & 7 & 8 & 9\end{array}$}

Figure 5 Affinity-labeling with $\mathrm{BrAc}\left[{ }^{125} \mid\right] T 3$ and Western blotting of D1 Cys protein and mutant proteins. (A) Labeling patterns obtained by SDS-PAGE and autoradiography after reaction of control yeast homogenate (lane 1) or homogenates containing D1 Cys (lane 2), D1 CysSer176 Ala (lanes 3 and 4), D1 Cys-Tyr209 Phe/Tyr217 Phe (lanes 5 and 6), D1 CysSer101 Ala (lanes 7 and 8), D1 Cys-Gly2 Ala (lanes 9 and 10), D1 Cys-Ser101 Ala/Ser176 Ala (lanes 11 and 12) or rat liver D1 protein (lane 13) with BrAc[125|]T3. The homogenates contained $20-25 \mu \mathrm{g}$ protein. Migration distances of molecular mass markers (kilodaltons) are indicated. (B) Labeling patterns obtained by SDS-PAGE and autoradiography after reaction of control yeast homogenate (lane 1) or homogenates containing D1 Cys (lane 2), D1 CysAsn94 GIn (lanes 3 and 4), D1 Cys-Asn203 GIn (lanes 5 and 6), D1 Cys-Asn94 GIn/Asn203 GIn (lanes 7 and 8) or rat liver D1 protein (lane 9) with $\mathrm{BrAc}\left[{ }^{125} \mid\right] \mathrm{T} 3$. The homogenates contained $20 \mu \mathrm{g}$ protein. Migration distances of molecular mass markers (kilodaltons) are indicated. (C) Western blot of homogenates (10 $\mathrm{\mu g}$ protein) containing D1 Cys (lane 1), D1 CysSer101 Ala (lane 2), D1 Cys-Ser176 Ala (lane 3), D1 Cys-Ser101 Ala/Ser176 Ala (lane 4), D1 Cys-Tyr209 Phe/Tyr217 Phe (lane 5), D1 Cys-Gly2 Ala (lane 6), D1 Cys-Asn94 Gln (lane 7), D1 Cys-Asn203 Gln (lane 8) and D1 Cys-Asn94 GIn/Asn203 GIn protein (lane 9).

and D1 Cys-Gly2 Ala protein over the membrane fractions was not different (Fig. 6G). So, there is no evidence for the involvement of $\mathrm{N}$-myristoylation in the membrane targeting of D1 Cys protein. 
Table 1 Kinetic characteristics of D1Cys mutant proteins

\begin{tabular}{|c|c|c|}
\hline & $\mathbf{K}_{\mathbf{m}}(\mu \mathrm{M})$ & $\mathbf{V}_{\max }(\mathrm{pmol} / \mathrm{min} / \mathrm{mg})$ \\
\hline \multicolumn{3}{|l|}{ Protein } \\
\hline D1Cys & $2 \cdot 8 / 2 \cdot 4$ & $162 / 120$ \\
\hline D1Cys-His tag & 1.7 & 87 \\
\hline D1Cys-Asn94GIn & 1.8 & 56 \\
\hline D1Cys-Asn203GIn & 4.5 & 61 \\
\hline D1Cys-Asn94GIn/Asn203Gln & 2.9 & 19 \\
\hline D1Cys-Ser101Ala & $2 \cdot 2 / 3 \cdot 2$ & $84 / 94$ \\
\hline D1Cys-Ser176Ala & $2 \cdot 0 / 2 \cdot 4$ & $96 / 84$ \\
\hline D1Cys-Ser101Ala/Ser176Ala & $>5 />5$ & $112 / 57$ \\
\hline D1Cys-Tyr209Phe/Tyr217Phe & $>5 />5$ & $61 /-$ \\
\hline D1Cys-Gly2Ala & $1 \cdot 5 / 2 \cdot 4$ & $100 / 91$ \\
\hline
\end{tabular}

Two values in the same column are the results of duplicate determinations.

\section{Discussion}

Establishment of an overexpression system aimed at the production of active Dl protein is important in order to enable studies on cellular targetting and processing, as well as structure determination via either electron or X-ray crystallography (Schmidt-Krey et al. 1998, Caffrey 2003). The overexpression of Dl protein represents a challenge because of several of its intrinsic properties: (1) the presence of an $\mathrm{SeC}$ residue in the catalytic center, (2) being an integral membrane protein, and (3) the requirement of a suitable native-like lipid environment essential for stability and catalytic activity upon purification (Mol et al. 1988). Although it is possible to overexpress certain SeC-containing proteins in $E$. coli (Müller et al. 1994), the expression of integral membrane proteins is difficult due to the lack of intracellular membranes into which proteins can sequester and fold. Initial attempts to overexpress D1 Cys protein in E. coli yielded large amounts of insoluble proteins which could not be renatured (not shown). Eukaryotic cells, such as insect and COS cells, can produce SeC-containing proteins but only in limited amounts (Berry et al. 1992, 1993, Kim et al. 1997, Kuiper et al. 2003) due to the inefficient synthesis of SeC-(Ser)-tRNA.

We believe that our system, involving expression of Dl Cys protein in yeast, is a good compromise. Substitution of Cys for SeC (i.e. sulfur for selenium) causes a 10 -fold increase in the apparent $K_{\mathrm{m}}$ value of the enzyme rT3 ORD, compared with native D1 in rat liver microsomes. The substrate turnover number is about 200 -fold reduced compared with native D1, i.e. $4 / \mathrm{min}$ vs $800 / \mathrm{min}$ (our results and Schoenmakers et al. 1992). Similar results, i.e. a 10 -fold increased $K_{\mathrm{m}}$ value and a 100 -fold decreased substrate turnover number were reported for the D1 Cys protein expressed in COS cells (Berry et al. 1991b, 1992). After affinity-labeling with $\mathrm{BrAc}\left[{ }^{125} \mathrm{~T}\right] \mathrm{T} 3$ of D1 Cys protein in COS cell homogenates, a single protein with apparent molecular mass of $27 \mathrm{kDa}$ was detected after SDS-PAGE (Berry et al. 1992). The fact that D1 Cys protein in COS cell homogenates $(27 \mathrm{kDa})$ and yeast cell homogenates $(27-$ $32 \mathrm{kDa}$ isoforms) have similar kinetic characteristics suggests that the isoform heterogeneity of the yeastexpressed protein does not change the enzyme kinetic properties. The ORD of rT3 by D1 Cys was essentially insensitive to PTU, showing that inhibition by PTU is highly dependent on the selenium atom in D1. Most likely, PTU inhibition is due to the formation of an enzyme-Se-S-PTU adduct (Visser 1980). In D1 Cys protein the formation of a mixed disulfide (enzyme-S-SPTU) is either unlikely or the mixed disulfide is unstable. In comparison, the reduction in sensitivity for the covalent affinity-label BrAcT3 was only minor. The content of D1 Cys present in yeast microsomes is about 20-fold higher than the D1 content in rat liver microsomes, i.e. $65 \mathrm{pmol} / \mathrm{mg}$ vs $3 \mathrm{pmol} / \mathrm{mg}$. The amount of D1 Cys protein produced (about $0 \cdot 1 \mathrm{mg} / \mathrm{l}$ yeast culture) is in principle enough for the identification of radiolabeled amino acid residue(s) after affinitylabeling with BrAc- $\left[{ }^{125} \Pi\right]$ iodothyronine derivatives (BrAcT3, BrAcT4, BrAcrT3) and sequencing of purified radioactive peptides. Site-directed mutagenesis of this identified substrate interacting residue(s) in the context of D1 Gys and Dl SeC protein could provide more insight in the molecular details of iodothyroninedeiodinase recognition. As already stated, the expression of D1 Cys in yeast is a compromise, as the substitution of SeC by Cys in the catalytic center leads to significant changes in substrate specificity and inhibitor profile. It remains to be determined whether it will be possible to extract and subsequently purify the Dl Cys-His-tag protein in the amounts needed for further structural analysis. No systems are available to overexpress the native (SeC containing) enzyme and therefore structural characterisation of the D1 Cys protein might be a good starting point. However, at this moment it remains an open question whether it will be possible to model the structure of the native D1 enzyme on that of the D1 Cys protein. 
Subcellular fractionation experiments showed that in yeast the Dl Cys protein is membrane-bound. The $10000 \boldsymbol{g}$ and $100000 \boldsymbol{g}$ membrane pellets contained about equal amounts of Dl Cys protein, and sucrose-density gradient analysis confirmed that the D1 Cys protein is divided over the ER, Golgi complex and plasma membrane. This is in line with data generated by the P-Sort (Nakai \& Horton 1999) and TargetP
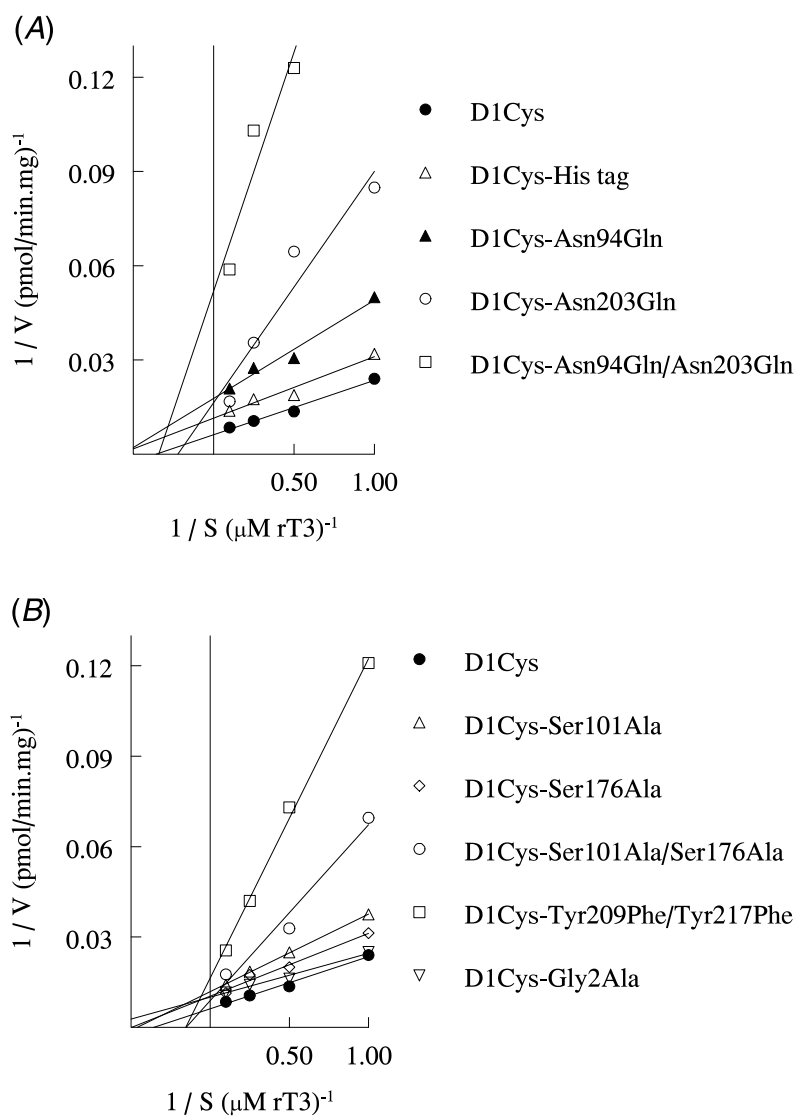

(C)

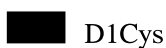

D1Cys-Gly2Ala

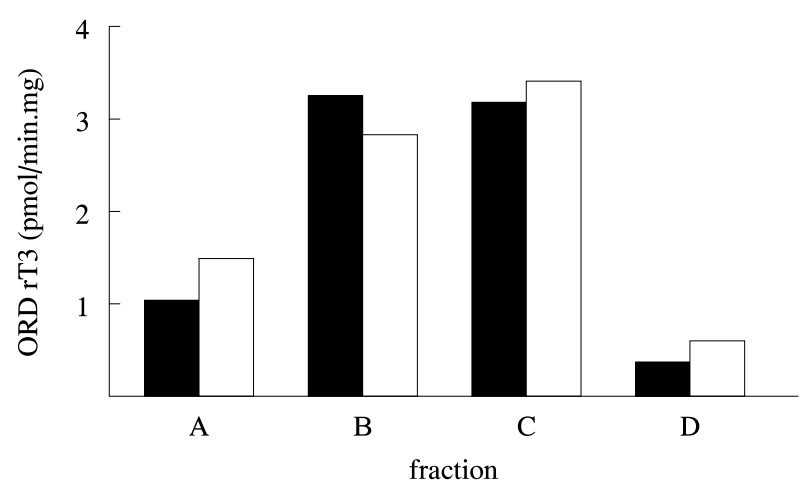

(Emanuelsson et al. 2000) predictive models for subcellular protein localization. Both models predict that the D1 protein contains an uncleaved signal peptide and is divided over ER, Golgi complex and plasma membrane. There is general agreement that D1 is an integral membrane protein but different cellular localizations have been found. In rat kidney, D1 is present in the plasma membrane (Leonard \& Rosenberg 1978, Leonard et al. 1991, 2001), while in rat liver D1 may be present in the ER with its active site oriented to the cytoplasm (Auf dem Brinke et al. 1979, Fekkes et al. 1979, Toyoda et al. 1995b). By immunofluorescence confocal microscopy the $\mathrm{D} 1$ protein was localized to the plasma membrane of transiently transfected COS cells (Baqui et al. 2000). Perhaps the D1 protein is incorporated in two topologies in the ER membrane, that is a type I orientation (N-terminus luminal/C-terminus cytosolic) and a type II orientation (N-terminus cytosolic/C-terminus luminal). In this model, the type I orientation would result in ERretention, while the type II orientation is associated with transport to the Golgi complex and plasma membrane. The extent to which the $\mathrm{D} 1$ is divided over the type I and type II orientations could be cell-type dependent thus explaining the different localizations found. Cytochrome P450 enzymes are also localized in the ER and plasma membrane. For CYP 2E1 it was shown that the N-terminal transmembrane domain plays a critical role in directing the protein to the plasma membrane. The topological inversion (type II orientation) of a part of the CYP 2E1 protein directs it to the plasma membrane while the remainder is retained in the ER in a type I orientation (Neve \& Ingelman-Sundberg 2000). Yeast could be a useful model system for studying the targeting of D1 and especially the role of the hydrophobic N-terminal transmembrane domain, much in the same way as has been done for CYP 2E1 (Neve et al. 2003).

Surprisingly, the D1 Cys $(\triangle 2-35)$ His-tag protein was still membrane associated and absent from the cytosolic fraction. Hydropathy analysis and in vitro translation studies using pancreatic microsomes have identified a single transmembrane sequence between amino acid residues 13 to 34 of rat D1 (Toyoda et al. 1995b). The

Figure 6 Kinetic characterisation of D1 Cys mutant proteins. (A) Double reciprocal plots of $125 \mathrm{I}-\mathrm{rT} 3 \mathrm{ORD}$ by homogenates containing D1 Cys, D1 Cys-His-tag and D1 Cys protein with mutations of potential N-linked glycosylation sites (Asp94 and Asp203). (B) Double reciprocal plots of ${ }^{125}$ I-rT3 ORD by homogenates containing D1 Cys and D1 Cys protein with mutations of potential phosphorylation sites (Ser101, Ser176, Tyr209, Tyr217) or N-linked myristoylation site Gly2. (C) Subcellular fractionation of yeast cells expressing D1 Cys (solid bars) or D1 Cys-Gly2 Ala (open bars) protein. The rT3 ORD activity (100 nM 125|-rT3) was measured in fractions A (1000 $g$ supernatant), B (10 $000 \mathrm{~g}$ pellet), C (100 $000 \mathrm{~g}$ pellet) and D (100 $000 \mathrm{~g}$ supernatant). 
fact that D1 Cys $(\triangle 2-35)$ His-tag is not cytosolic might point to the existence of alternative transmembrane domain(s). The HMMTOP-model, which is based on the hypothesis that topology of membrane proteins is determined by maximal divergence of the various structural parts, predicts two transmembrane domains between amino acid residues $13-33$ and 56-75 for rat D1 (Tusnády \& Simon 1998). The first transmembrane domain (13-33) has a fivefold higher probability than the second one. It should also be noted that the D1 Cys $(\triangle 2-35)$ His-tag protein is inactive, probably due to improper folding. Very similar results have been obtained after overexpression of $11 \beta$-hydroxysteroid dehydrogenase and CYP 2E1 in yeast, i.e. membrane attachment despite deletion of the hydrophobic N-terminal membrane anchor sequence (Blum et al. 2001, Neve et al. 2003). Whether these results are related to the overexpression in yeast or truly reflect the existence of additional transmembrane domains remains to be investigated.

From the immunoblotting and affinity-labeling data it is clear that while native $\mathrm{D} 1$ protein (rat liver) migrates as a single $27 \mathrm{kDa}$ protein on SDS-PAGE the Dl Cys protein is present as several isoforms with molecular masses between 27 and $32 \mathrm{kDa}$. This difference is most likely caused by differential post-translational modification. There is no experimental evidence available for any post-translational modification of native $\mathrm{D} 1$ protein or D1 Cys expressed in COS cells. So, the D1 Cys heterogeneity is a special feature connected to the expression in yeast cells. The heterogeneity might be caused by a combination of several common modifications of proteins expressed in yeast such as phosphorylation, N-linked glycosylation, O-linked glycosylation and fatty acid acylation (Tanner \& Lehle 1987, Simon \& Aderem 1992, Li et al. 2001). By site-directed mutagenesis of consensus N-linked glycosylation sites and treatment with $\mathrm{N}$-glycosidases, we found no evidence for N-linked glycosylation and it appears to be excluded. O-linked glycosylation begins in yeast in the ER by addition of a single mannose to either Ser or Thr residues and once transported to the Golgi complex sugar transferases add one or more mannose units (Tanner \& Lehle 1987, Gemmill \& Trimble 1999). It is difficult to prove possible O-linked glycosylation of D1 Cys protein since no glycosidases aimed at mannose sugars are available and chemical deglycosylation with hydrogen fluoride of O-linked sugars is often not complete or destroys the polypeptide chain (Sojar \& Bahl 1987). In various instances Ser or Thr phosphorylation sites are also targets for O-linked glycosylation. We mutated several potential phosphorylation sites (Ser 101 and 176) but this did not change D1 Cys heterogeneity. Many more (21 in total) Ser or Thr residues are present in D1 Cys protein and they could all be targets for O-linked glycosylation. All in all, we have no evidence for O-linked glycosylation but we also cannot exclude it as a cause of D1 Cys heterogeneity. Site-directed mutagenesis of several consensus phosphorylation sites provided evidence for phosphorylation at Tyr residues 209 and/or 217 (downshift of complete isoform pattern). Phosphorylation at other site(s) by kinases with unknown specificity cannot be excluded.

N-Myristoylation is a common modification of eukaryotic membrane proteins, and there is ample evidence that myristoylation is involved in membrane attachment and targeting of these proteins (Simon \& Aderem 1992, Manahan et al. 2000, Chen \& Manning 2001). The rat D1 protein fulfils the minimal requirement for N-linked myristoylation, that is an N-terminal Met-Gly sequence (Utsumi et al. 2001). On the other hand the MYR predictor program (MaurerStroh et al. 2002), which is based upon the substrate specificity and structure of the eukaryotic enzyme myristoyl-CoA-protein $\mathrm{N}$-myristoyltransferase (NMT) does not predict myristoylation of the $\mathrm{D} 1$ protein. In various cases it has been shown by site-directed mutagenesis (Gly2 Ala) that disturbed myristoylation of G-protein subunits in yeast cells causes mislocalization of protein, resulting in accumulation of inactive proteins in ER and Golgi complex (Song et al. 1996). In contrast, the D1 Cys-Gly2 Ala mutant protein had kinetic characteristics and membrane distribution properties which are indistinguisable from those for the D1 Cys protein. Therefore, although part of the Dl Cys protein might be myristoylated (based on the different isoform pattern on SDS-PAGE of D1 Cys-Gly2 Ala) there is no evidence for a functional role.

In summary, heterologous expression of D1 Cys protein in yeast resulted in the overproduction of a membrane-bound bioactive enzyme. Although the D1 Cys protein expressed in yeast is posttranslationally modified in a different manner to the D1 Cys protein expressed in COS cells the kinetic characteristics are similar. Future experiments will be aimed at purification of the D1 Cys protein and overexpression in other yeast strains such as Pichia pastoris or Hansenula polymorpha, which could result in even higher expression levels and more authentic post-translational modification characteristics (Bill 2001, Li et al. 2001).

\section{Acknowledgements}

This work was supported by The Netherlands Organization of Scientific Research (grant number 903-40-194) and the FP5 Quality of Life Research program of the European Union (contract number QLG3-CT-2000-00930). The authors declare that there is no conflict of interest that would prejudice the impartiality of this scientific work. 


\section{References}

Auf Dem Brinke D, Hesch RD \& Köhrle J 1979 Re-examination of the subcellular localization of thyroxine $5^{\prime}$-deiodination in rat liver. Biochemical fournal 180 273-279.

Baqui MMA, Gereben B, Harney JW, Larsen PR \& Bianco AC 2000 Distinct subcellular localization of transiently expressed types 1 and 2 iodothyronine deiodinases determined by immunofluorescence confocal microscopy. Endocrinology 141 $4309-4312$.

Berry MJ, Banu L \& Larsen PR 1991a Type I iodothyronine deiodinase is a seleno- cysteine containing enzyme. Nature $\mathbf{3 4 9}$ 438-440.

Berry MJ, Kieffer JD, Harney JW \& Larsen PR $1991 b$ Selenocysteine confers the biochemical properties characteristic of the type I iodothyronine deiodinase. Fournal of Biological Chemistry 266 14155-14158.

Berry MJ, Maia AL, Kieffer JD, Harney JW \& Larsen PR 1992 Substitution of cysteine for selenocysteine in type I iodothyronine deiodinase reduces the catalytic efficiency of the protein but enhances its translation. Endocrinology 131 1848-1852.

Berry MJ, Banu L, Harney JW \& Larsen PR 1993 Functional characterization of the eukaryotic SECIS elements which direct selenocysteine insertion at UGA codons. EMBO fournal 12 $3315-3322$.

Bianco AC, Salvatore D, Gereben B, Berry ML \& Larsen PR 2002 Biochemistry, cellular and molecular biology, and physiological roles of the iodothyronine deiodinases. Endocrine Reviews 23 38-89.

Bill RM 2001 Yeast: a panacea for the structure-function analysis of membrane proteins? Current Genetics 40 157-171.

Blom N, Gammeltoft S \& Brunak S 1999 Sequence- and structure-based prediction of eukaryotic protein phosphorylation sites. Fournal of Molecular Biology 294 1351-1362.

Blum A, Raum A, Martin H-J \& Maser E 2001 Human $11 \beta$-hydroxysteroid dehydrogenase 1/carbonyl reductase: additional domains for membrane attachment? Chemico Biological Interactions 130-132 749-759.

Caffrey M 2003 Membrane protein crystallization. Fournal of Structural Biology 142 108-132.

Chen CA \& Manning DR 2001 Regulation of G proteins by covalent modification. Oncogene 20 1643-1652.

Doorn van J, van der Heide D \& Roelfsema F 1983 Sources and quantity of 3,5, $3^{\prime}$ - triiodothyronine in several tissues of the rat. fournal of Clinical Investigation 72 1778-1792.

Eelkman Rooda SJ, van Loon MAC \& Visser TJ 1987 Metabolism of reverse triiodothyronine by isolated rat hepatocytes. Fournal of Clinical Investigation 79 1740-1748.

Emanuelsson O, Nielsen H, Brunak S \& von Heijne G 2000 Predicting subcellular localization of proteins based on their $\mathrm{N}$-terminal amino acid sequence. Fournal of Molecular Biology $\mathbf{3 0 0}$ 1005-1016 (see http://www.cbs.Dtu.dk/services/TargetP/).

Franzusoff A, Rothblatt J \& Schekman R 1991 Analysis of polypeptide transit through yeast secretory pathway. Methods in Enzymology 194 662-674.

Fekkes D, van Overmeeren-Kaptein E, Docter R, Hennemann G \& Visser TJ 1979 Location of rat liver iodothyronine deiodinating enzymes in the endoplasmic reticulum. Biochimica et Biophysica Acta $58712-19$

Gemmill TR \& Trimble RB 1999 Overview of N- and O-linked oligosaccharide structures found in various yeast species. Biochimica et Biophysica Acta 1426 227-237.

Griffith DA, Delipala C, Leadsham J, Jarvis SM \& Oesterhelt D 2003 A novel yeast expression system for the overproduction of quality-controlled membrane proteins. FEBS Letters $\mathbf{5 5 3} 45-50$.

Guengerich FP, Brian WR, Sari M-A \& Ross JT 1991 Expression of mammalian cytochrome P450 enzymes using yeast based vectors. Methods in Enzymology 206 130-145.
Halligan BD, Ruotti V, Jin W, Laffoon S, Twigger SN \& Dratz EA 2004 ProMoST (protein modification screening tool): a web-based tool for mapping protein modifications on two-dimensional gels. Nucleic Acid Research 32 W638-W644.

Hasper A, Soteropoulos P \& Perlin DS 1999 Modification of the N-terminal polyserine cluster alters stability of the plasma membrane $\mathrm{H}^{+}$-ATPase from Saccharomyces cerevisiae. Biochimica et Biophysica Acta $1420214-222$.

Hennemann G \& Visser TJ 1997 Thyroid hormone synthesis, plasma membrane transport and metabolism. Handbook of Experimental Pharmacology 128 76-117.

Hult M, Nobel CSI, Abrahmsen L, Nicoll-Griffith DA, Jornvall H \& Oppermann UCT 2001 Novel enzymological profiles of human $11 \beta$-hydroxysteroid dehydrogenase type 1. Chemico Biological Interactions 130-132 805-814.

Ito H, Fukuda Y, Murata K \& Kimura A 1983 Transformation of intact yeast cells treated with alkali cations. Foumal of Bacteriology $153163-168$

Kaiser CA, Chen EJ \& Losko S 2002 Subcellular fractionation of secretory organelles. Methods in Enzymology 351 325-338.

Kim IY, Guimarães MJ, Zlotnik A, Bazan JF \& Stadtman TC 1997 Fetal mouse selenophosphate synthetase 2: characterization of the cysteine mutant form over- produced in a baculovirus-insect cell system. PNAS 94 418-421.

Köhrle J 2002 Iodothyronine deiodinases. Methods in Enzymology 347 125-167.

Köhrle J, Rasmussen UB, Ekenbarger DM, Alex S, Rokos H, Hesch RD \& Leonard JL 1990 Affinity labeling of rat liver and kidney type I deiodinase. Fournal of Biological Chemistry 265 6155-6163.

Kuiper GGJM, Wassen F, Klootwijk W, van Toor H, Kaptein E \& Visser TJ 2003 Molecular basis for the substrate selectivity of cat type I iodothyronine deiodinase. Endocrinology 144 5411-5421.

Kuiper GGJM, Kester MHA, Peeters RP \& Visser TJ 2005 Biochemical mechanisms of thyroid hormone deiodination. Thyroid In Press.

Leonard JL \& Rosenberg IN 1978 Subcellular distribution of thyroxine $5^{\prime}$-deiodinase in the rat kidney: a plasma membrane location. Endocrinology $103274-280$.

Leonard JL, Ekenbarger DM, Frank SJ, Farwell AP \& Köhrle J 1991 Localization of type I iodothyronine 5'-deiodinase to the basolateral plasma membrane in renal cortical epithelial cells. Fournal of Biological Chemistry 266 11262-11269.

Leonard JL, Visser TJ \& Leonard DB 2001 Characterization of the subunit structure of catalytically active type I iodothyronine deiodinase. Fournal of Biological Chemistry 276 2600-2607.

Lescure A, Gautheret D, Carbon P \& Krol A 1999 Novel selenoproteins identified in silico and in vivo by using a conserved RNA structural motif. Fournal of Biological Chemistry $\mathbf{2 7 4}$ 38147-38154

Li P, Gao X-G, Arellano RO \& Renugopalakrishnan V 2001 Glycosylated and phosphorylated proteins - expression in yeast and oocytes of Xenopus: prospects and challenges. Protein Expression and Purification 22 369-380.

Liang X, Lu Y, Neubert TA \& Resh MD 2002 Mass spectrometric analysis of GAP-43/neuromodulin reveals the presence of a variety of fatty acetylated species. Fournal of Biological Chemistry $\mathbf{2 7 7}$ 33032-33040.

Manahan CL, Patnana M, Blumer KJ \& Linder ME 2000 Dual lipid modification motifs in $\mathrm{G} \alpha$ and $\mathrm{G} \gamma$ subunits are required for full activity of the pheromone response pathway in Saccharomyces cerevisiae. Molecular Biology of the Cell 11 957-968.

Maurer-Stroh S, Eisenhaber E \& Eisenhaber F 2002 N-terminal $\mathrm{N}$-myristoylation of proteins: prediction of substrate proteins from amino acid sequences. Fournal of Molecular Biology 317 541-557.

Mol JA, Docter R, Kaptein E, Jansen G, Hennemann G \& Visser TJ 1984 Inactivation and affinity-labeling of rat liver 
iodothyronine deiodinase with N-bromoacetyl-3,3',5-

triiodothyronine. Biochemical and Biophysical Research Communications 124 475-483.

Mol JA, van den Berg TP \& Visser TJ 1988 Partial purification of the microsomal rat liver iodothyronine deiodinase. Molecular and Cellular Endocrinology 55 149-166.

Moreno M, Berry MJ, Horst C, Thoma R, Coglia F, Harney JW, Larsen PR \& Visser TJ 1994 Activation and inactivation of thyroid hormone by type I iodothyronine deiodinase. FEBS Letters 344 143-146.

Müller S, Senn H, Gsell B, Vetter W, Baron C \& Böck A 1994 The formation of diselenide bridges in proteins by incorporation of selenocysteine residues: biosynthesis and characterisation of (Se)2-thioredoxin. Biochemistry 33 3404-3412.

Nakai K \& Horton P 1999 PSORT: a program for detecting sorting signals in proteins and predicting their subcellular localization. Trends in Biochemical Sciences 24 34-36 (see http://www.hgc.ims. u-tokyo.ac.jp/knakai/).

Neve EPA \& Ingelman-Sundberg M 2000 Molecular basis for the transport of cytochrome $\mathrm{P} 4502 \mathrm{E} 1$ to the plasma membrane. fournal of Biological Chemistry 275 17130-17135.

Neve EPA, Hidestrand M \& Ingelman-Sundberg M 2003 Identification of sequences responsible for intracellular targeting and membrane binding of rat CYP 2E1 in yeast. Biochemistry $\mathbf{4 2}$ 14566-14575.

Nguyen TT, Chapa F \& DiStefano III JJ 1998 Direct measurement of the contributions of type I and type II 5 '-deiodinases to whole body steady state 3,5,3'-triiodothyronine production from thyroxine in the rat. Endocrinology 139 4626-4633.

Orlean P, Kuranda MJ \& Albright CF 1991 Analysis of glycoproteins from Saccharomyces cerevisiae. Methods in Enzymology 194 682-698.

Parikh A \& Guengerich FP 1998 Random mutagenesis by whole-plasmid PCR amplification. BioTechniques 24 428-431.

Patterson SI \& Pate Skene JH 1995 Inhibition of dynamic protein palmitoylation in intact cells with tunicamycin. Methods in Enzymology 250 284-300.

Sambrook J \& Russell DW 2001 In vitro mutagenesis using double-stranded DNA templates: selection of mutants with DpnI. In Molecular Cloning, a Laboratory Manual, pp 13·19-13·25. Cold Spring Harbor, NY: Cold Spring Harbor Press.

Schmidt-Krey I, Lundqvist G, Morgenstern R \& Hebert H 1998 Parameters for the two- dimensional crystallisation of the membrane protein microsomal glutathione transferase. Fournal of Structural Biology 123 87-96.

Schneppenheim R, Budde U, Dahlmann N \& Rautenberg P 1991 Luminography - a new, highly sensitive visualization method for electrophoresis. Electrophoresis 12 367-372.

Schoenmakers C, Pigmans I, Hawkins H, Freedman R \& Visser TJ 1989 Rat liver type I iodothyronine deiodinase is not identical to protein disulfide isomerase. Biochemical and Biophysical Research Communications 162 857-868.
Schoenmakers CHH, Pigmans IGAJ \& Visser TJ 1992 Species differences in liver type I iodothyronine deiodinase. Biochimica et Biophysica Acta 1121 160-166.

Sherman F 1991 Getting started with yeast. Methods in Enzymology $1943-21$.

Simon SM \& Aderem A 1992 Myristoylation of proteins in the yeast secretory pathway. Fournal of Biological Chemistry 267 3922-3931.

Sojar HT \& Bahl OP 1987 Chemical deglycosylation of glycoproteins. Methods in Enzymology 138 341-350.

Song J, Hirschman J, Gunn K \& Dohlman HG 1996 Regulation of membrane and subunit interactions by N-myristoylation of a $\mathrm{G}$ protein alpha subunit in yeast. Fournal of Biological Chemistry 271 20273-20283.

Tanner W \& Lehle L 1987 Protein glycosylation in yeast. Biochimica et Biophysica Acta 906 81-99.

Toyoda N, Harney JW, Berry MJ \& Larsen PR 1995a Identification of critical amino acids for 3,3',5'-triiodothyronine deiodination by human type I deiodinase based on comparative

functional-structural analysis of the human, dog and rat enzymes. fournal of Biological Chemistry 269 20329-20334.

Toyoda N, Berry MJ, Harney JW \& Larsen PR $1995 b$ Topological analysis of the integral membrane protein, type I iodothyronine deiodinase. Fournal of Biological Chemistry 270 12310-12318.

Toyoda N, Kaptein E, Berry MJ, Harney JW, Larsen PR \& Visser TJ 1997 Structure- activity relationships for thyroid hormone deiodination by mammalian type I iodothyronine deiodinases. Endocrinology 138 213-219.

Tusnády GE \& Simon I 1998 Principles governing amino acid composition of integral membrane proteins: application to topology prediction. Fournal of Molecular Biology 283 489-506 (see http://www.enzim.hu/hmmtop/server/hmmtop.cgi) .

Utsumi T, Sato M, Nakano K, Takemura D, Iwata H \& Ishisaka R 2001 Amino acid residue penultimate to the amino-terminal Gly residue strongly affects two cotranslational protein modifications, $\mathrm{N}$-myristoylation and N-acetylation. Fournal of Biological Chemistry 276 10505-10513.

Visser TJ 1980 Mechanism of inhibition of iodothyronine 5 '-deiodinase by thioureylenes and sulfite. Biochimica et Biophysica Acta $611371-378$

Visser TJ, Fekkes D, Docter R \& Hennemann G 1978 Sequential deiodination of thyroxine in rat liver homogenate. Biochemical fournal 174 221-229.

Visser TJ, Mol JA \& Otten MH 1983 Rapid deiodination of triiodothyronine sulfate by rat liver microsomal fraction. Endocrinology 112 1547-1549.

Wong H-Y, Burghoorn J, van Leeuwen M, de Ruiter PE, Schippers E, Blok L, Li KW, Dekker H, de Jong L, Trapman J, Grootegoed J \& Brinkmann AO 2004 Phosphorylation of androgen receptor isoforms. Biochemical fournal $\mathbf{3 8 3} 267-276$.

Received 1 March 2005

Accepted 7 March 2005 